\title{
TEACHING UNDERGRADUATES
}

Topic: What Is the Theologian Doing?

Convener: Paul Lakeland, Fairfield University

Panelists: Mary Gerhart, Hobart and William Smith Colleges

Mary Hines, Emmanuel College

Michelle Gonzalez, Loyola Marymount University

Vincent Miller, Georgetown University

The four members of the panel represented four very different institutions, while the panelists included two at early stages of their careers, and two who have devoted many years to teaching. Each addressed different aspects of the classroom challenges facing the undergraduate teacher who is also a theologian.

Of the four, Mary Gerhart is the one who does not teach in a Catholic institution, and her remarks consequently focused on the ways in which the theologian addresses religious issues in a more secular environment. She outlined some of the particular history of Hobart and William Smith Colleges, and some of the details of her courses. The challenges in this context are to remain faithful to the theologian's concern for the exploration of fundamental issues of meaning and the examination of various dimensions of religious experience, while attending to the character of an institution which, while nominally in the Episcopalian tradition, has in effect no explicit religious commitments or identity.

Michelle Gonzalez reflected on the transition from the intellectual sophistication of graduate school to the classroom in which far more basic questions are often at issue. She spoke of her excitement at this development, motivated by her sharing the common understanding among Hispanic theologians of the vocational character of the work. She suggested three motifs that characterize her approach to her work; faith, passion and praxis. Students must be led to see faith as more than mere feeling, and that it presents a legitimate set of challenges to typical academic understandings of intellectual discourse. Passion in the teacher is what makes learning a transformative event for students, and so passion and emotion are things we should not be afraid of in the classroom. Praxis is important not only by attending to the contextual realities of all theology, but also in the promotion of service learning in coursework. Finally, exploring popular religion is also a means to highlight praxis in the classroom.

Mary Hines began by suggesting that work with undergraduates is a kind of laboratory through which we can determine the appropriate role of the theologian in the postmodern world. Students are suspicious of totalizing narratives, comfortable with both globalization and pluralism. They often assert that they are suspicious of organized religion but interested in spiritual issues. So much of our work with undergraduate students is modeling what our work as a whole ought to be, attending to the process through which people today undertake their own search for meaning, often in dialogue with more traditional approaches. Very 
little work with undergraduates is the classic systematic exposition of the content of the religious tradition. In fact, what we are doing is a kind of fundamental theology for the modern world, reflecting on the conditions of possibility for belief today.

Vince Miller explored the development of his teaching during his time at Georgetown, stressing the modifications that need to be made, and those that should not be made, to accommodate the postmodern sensibilities of students. He then offered two different implications for the theologian's work for the church that arise from working with undergraduates. First, we provide early warnings of cultural changes, which our proximity to young people places us in a privileged position to identify. Teaching them as we do, our capacity for refining fundamental theology may be increased. Rather than hermeneutics, we have to address questions about the attachment of a skeptical and yet credulous generation to traditions, communities and institutions. Second, more closely related to the systematic task of the theologian, we need to face the question of theological literacy. What should we really expect students to know when they come to class, and what can we realistically expect to add in one or two courses?

The ensuing lively discussion focused on the ways in which our tasks change in response to the so-called postmodern imperatives of globalization, pluralism, relativism, and so on. The group, in other words, seemed to take up the implicit theme of the panelists that the undergraduate teacher as theologian is engaged in the creation of a new fundamental theology.

PAUL LAKELAND

Fairfield University

Fairfield, Connecticut

\section{$\left.{ }^{*}{ }^{*}\right|^{*}$}

\section{RELIGIOUS PLURALISM AND THE VOCATION OF THE THEOLOGIAN}

Topic: Dialogue and Doctrine

Convener: Catherine Cornille, Boston College

Presenters: Paul Griffiths, University of Illinois at Chicago

David Burrell, University of Notre Dame

John Keenan, Middlebury College

Monika Hellwig, Association of Catholic Colleges and Universities

The four panelists in this session offered remarks on the relationship between interreligious dialogue and Christian doctrine, or on how their involvement with other religions had affected their attitude toward doctrine in general or toward particular doctrines. Paul Griffiths, who is both a renowned specialist in Indian Buddhism and a Catholic theologian and philosopher, argued that the need for 